пониманию. Следовательно, журналисты часто прибегают к употреблению неологизмов.

Рассмотрены понятия неологизмов и их типология. Отмечено, что существуют различные параметры определения термина «неология»: процесс создания новых лексических единиц строится в соответствии с обычными механизмами творческого процесса в развитии речи; теоретическое и прикладное исследование создания лексических единиц, способы образования слов, критерии признания, принятия и распространения неологизмов, социокультурные аспекты неологии; систематически организованная деятельность институтов для учета, создания, записи, распространения и внедрения неологизмов в четкие рамки языковой политики; задача по установлению новых терминосистем и недавно созданных отраслей, имеющих пробелы в терминологии и требующих ее внедрения; лексикографическая система отношений со словарями, которая исходит из двух аспектов: использование словаря в качестве фильтрующего средства по признанию неологизмов и анализ их обработки внутри словарей.

Рассмотрены функциональные особенности использования неологизмов в медиатексте. Результаты анализа позволяют сделать выводы, что неологизмы довольно распространены в газетных текстах, находят свое отражение в статьях различной тематики (экономической, деловой, развлекательной, молодежной прессе и др.), создавая в каждой из них свой стилистический эффект. Отмечено, что передача неологизмов в украинском языке осуществляется с привлечением таких способов перевода, как уподобление, описательный перевод, калькирование, транскрибирование, транслитерация.

Ключевые слова: лексика, неологизм, перевод, медиа, медиатекст

Valchuk Halyna. Pragmatic Functionality of Neologisms in English-Language Media Texts. The article is devoted to actual problems of the functioning and translation of neologisms in the media texts of the modern Englishlanguage press. In the course of the study, the definition of "media text" is given. The stylistic features of English-language media texts are characterized. It is noted that the language of English-language media texts has certain features and is aimed at certain categories of readers. During the analysis of English-language media, a direct relationship between the degree of complexity of the selected language tools and the sociocultural specific features of the target audience is proved.

It was emphasized that most of the specific vocabulary in English-language media is socio-political vocabulary. Political texts are connected with the task of simultaneously and clearly conveying the events of the world of politics, and not overly complicating and overloading the message with various terms that would interfere with its understanding. Consequently, journalists often resort to the use of neologisms.

The concepts of neologisms and their typology are considered. It is noted that there are various parameters for the definition of the term "neology": the process of creating new lexical units is built in accordance with the usual mechanisms of the creative process in the development of speech; theoretical and applied research on the creation of lexical units, ways of forming words, criteria for recognition, acceptance and dissemination of neologisms, sociocultural aspects of neology; systematically organized activities of institutes for accounting, creating, recording, disseminating and introducing neologisms into a clear framework of language policy; the task of establishing new terminology systems and recently created industries that have gaps in terminology and require its implementation; a lexicographic system of relations with dictionaries, which proceeds from two aspects: using the dictionary as a filtering tool for recognizing neologisms and analyzing their processing inside dictionaries.

The functional features of the use of neologisms in the media text are considered. The results of the analysis allow us to conclude that neologisms are quite common in newspaper texts, are reflected in articles of various subjects (economic, business, entertainment, youth press, etc.), creating in each of them its own stylistic effect. It is noted that the transfer of neologisms in the Ukrainian language is carried out using such translation methods as assimilation, descriptive translation, tracing, transcribing, transliteration.

Key words: vocabulary, neologism, translation, media, media text

DOI: https://doi.org/10.32782/2410-0927-2020-12-5

УДК $821.111(73) .09: 81 ’ 255.4$

Ольга Василенко, Леся Костюк

\title{
ОСОБЛИВОСТІ СТАНОВЛЕННЯ УКРАЇНОМОВНИХ ПЕРЕКЛАДІВ ТВОРІВ ЕРНЕСТА ХЕМІНГУЕЯ В ХХ СТОЛІТТІ
}

Стаття присвячена дослідженню історичних передумов появи україномовних перекладів творів Ернеста Хемінгуея в XX столітті та основних чинників, які впливали на процес становлення україномовної практики. Зазначено, що відправною точкою цього складного процесу стала публікація в кінці 70-х - на початку 80-х років минулого століття чотиритомного видання творів Хемінгуея в українському перекладі. Одним із найактуальніших об'єктів перекладознавчого пошуку є художні тексти модерністського й постмодерністського напрямків. Манера письменника - лаконічна, стримана, економна і сувора. Враховуючи цей факт, перекладач повинен ретельно підбирати мовні еквіваленти перекладу, уникаючи буквалізму і розглядаючи твір як цілісну систему, що передає сюжетну лінію. Важливим кроком у становленні практики перекладів творів Е. Хемінгуея був відхід від

(C) Василенко О., Костюк Л., 2020 
словникового буквалізму до контекстуального відповідника оригіналу. У роботі визначено основні риси, притаманні україномовним інтерпретаціям творів американського письменника, зокрема використання фразеологізмів та тропів при перекладах прямої мови й діалогів, вживання автентичних українських слів 3 урахуванням статі літературного героя, його віку, суспільного статусу тощо, а також застосування прагматичної адаптації. Проаналізовано способи передачі індивідуальної манери Ернеста Хемінгуея художніми засобами української мови 3 врахуванням національних особливостей. Проведено паралелі між соціокультурним життям України в умовах ХХ століття та розвитком перекладацької діяльності на прикладі творів Хемінгуея. Зазначено, що суспільно-політична ситуація в країні визначала шлях розвитку перекладацької практики: це перешкоджання антиукраїнської політики появі україномовних перекладів як таких, і негативне ставлення до сутності творів Хемінгуея. Визначено головні фактори, які задавали вектор перекладацький діяльності та прямо чи опосередковано формували основні іiі тенденції. У контексті соціальних чинників проаналізовано напрямки впливу та визначено їхню роль у формуванні перекладознавства в Україні в другій половині минулого століття. Зазначено основні досягнення українських перекладачів у процесі інтерпретації творів Ернеста Хемінгуея українською мовою.

Ключові слова: індивідуально-авторський стиль, переклад, методи перекладу, лексична трансформація, контекстуальний відповідник.

Постановка проблеми та іï значення. Творчий спадок великого американського письменника-модерніста XX століття Ернеста Хемінгуея являє собою великий інтерес для літературознавчих та лінгвістичних досліджень у всьому світі. Його авторський стиль демонструє унікальний письменницький талант, який формувався під впливом своєрідних особистісних якостей та багатого життєвого досвіду. Одним із найактуальніших об'єктів перекладознавчого пошуку слугують художні тексти модерністського й постмодерністського напрямків [6].

Український читач у минулому столітті був позбавлений можливості пізнавати твори Е. Хемінгуея рідною мовою, позаяк політика СРСР виключала будь-які можливості існування якісних перекладів найвизначніших творів митця. До кінця 1970-х років перекладознавство в Україні перебувало в стані занепаду. Проте саме тоді з'явилися перші україномовні інтерпретації практично всіх творів митця, які відрізняються самобутністю та широким спектром перекладацьких методик. Безперечно, це стало поштовхом до подальших досліджень робіт вітчизняних перекладачів.

Аналіз останніх досліджень і публікацій. До аналізу творчості Ернеста Хемінгуея в українському науковому просторі зверталися і звертаються до сьогодні неодноразово. Серед вчених, які займалися дослідженнями, є як вітчизняні науковці, так і зарубіжні - Р. Доценко [2], O. Тарнавський [11], A. Fawcett [14], S. Berman [18] та ін. 3 точки зору компаративістики, українськими адаптаціями творів Е. Хемінгуея цікавилися М. Лановик [7], Т. Денисова [1]. Здебільшого науковці схильні до твердження про те, що на стиль і сутність перекладу впливають соціальні та політичні чинники.

Мета статті - простежити шлях розвитку інтерпретацій Ернеста Хемінгуея в українському перекладознавстві XX століття.

Вихід у світ чотиритомного видання став наслідком появи праць низки перекладачів, чиї роботи ми досліджуємо в цій статті. Опираючись на авторський стиль В. Митрофанова, М. Пінчевського, Л. Гончар, Ю. Покальчука, К. Сухенко, Н. Тарасенко, дослідник може простежити основні тогочасні тенденції та засоби передачі авторського стилю Е. Хемінгуея українському читачеві з урахуванням національних особливостей.

Результати та дискусії. Процес перекладу та представлення творів Е. Хемінгуея українською мовою в XX столітті повністю залежав від суспільно-політичної ситуації в країні. По-перше, на заваді була антиукраїнська політика, яка унеможливлювала будь-які спроби інтелігенції створити інтерпретації рідною мовою, а, по-друге, сама сутність творів Хемінгуея була першопричиною негативного ставлення до їхнього потенційного масового поширення серед українців. Українська психологічна проза перебувала в кризовому стані, ослаблена й занедбана нормами соцреалізму. В середині 1950 - х років з'явилися передумови для плідної перекладацькою діяльності. Виникла нагальна потреба заповнити цю нішу якщо не зразками творів власного письменства, то хоча б світовою спадщиною. Перші видання творів Хемінгуея українською мовою з'явились у 1957 році. Тоді була опублікованана п'єса “П'ята колона". У 1961 році опублікований українською мовою роман Е. Хемінгуея «За річкою, у затінку дерев». 
Переклад здійснено К. Сухенко і Н. Тарасенко. Згодом у 1971 році світ побачив україномовний переклад В. Митрофанова "Весняні потоки" - маловідомий приклад раннього етапу творчості Хемінгуея. За словами перекладача Ростислава Доценка, в Україні з його творчості видана лише п’єса “П’ята колона”, яку сам автор визначав як одну з найбільш невдалих. Він наголошував, що у нас є два видання найслабшого його роману “За річкою, у затінку дерев” і немає жодного 3 його вершинних творів, як-от: “Старий і море”, “Прощавай, зброє!” [2, с. 163].

Визначна подія в історії українського перекладу сталася у 1979-1981 роках, яка ознаменувала появу чотиритомного видання творів Хемінгуея, де були вперше перекладені українською його найвідоміші твори. Ця подія мала ряд наслідків, серед яких можна виділити великий прогрес у процесі еволюції українського перекладознавства. Ряд дослідників навіть вважає, що перекладачам вдалося уникнути буквалізму, яким були перенасичені роботи 1930 50-х років. Д. Дюришин вважав, що стан літературного процесу часто визначає не лише вибір, а й метод перекладу [3, с.130].

Критики характеризують художню манеру письменника як лаконічну, стриману, економну, сувору. Відомо, що Е. Хемінгуей переписував сцени своїх творів понад 20 разів [8]. Очевидно, що така ретельність у підборі мовних засобів вимагає не меншої уважності від перекладача. Останній повинен бачити текст хемінгуеївської прози як систему, де лінгвістична форма є надзвичайно важливою для передачі кожного сюжетного фрагмента [5, с. 81].

Успіх перекладу стилістичних прийомів і стилістично забарвленої лексики залежить від адекватної передачі денотативного значення лексичної одиниці та правильного підбору еквіваленту з аналогічним стилістичним значенням і організацією контексту відповідно до його функціонального призначення. На думку С. Ковганюка, буквалізм панував у радянському перекладознавстві з певних причин. Страх “коли б чого не сталося", характерний для доби культу особи взагалі, механічно діяв й у галузі перекладу [4, с.40-41].

Таким чином, більшість українських перекладознавців впевнена в тому, що достатньо пізня поява перших перекладів творів Хемінгуея має свої переваги.

Спільною рисою для перекладачів кінця 1970-х - початку 1980-х років стала лексична трансформація конкретизації значення. Відбувся своєрідний перехід від словникових відповідників до контекстуальних. В. Кухаренко та К. Горшкова, відомі вітчизняні мовознавці, виділяють стилістичні компоненти хемінгуеївського стилю, що не повинні піддаватися компенсаціям чи замінам. Загалом Е. Хемінгуей надзвичайно часто використовує у своїх творах вказівні займенники. 3'являючись переважно на початку фрази, вони апелюють до нібито знайомих читачеві фактів, створюють ефект повернення до попередньої теми розмови, одним словом, організовують імплікацію передування [6]. Водночас справедливо було б зазначити, що в модерністських текстах вказівний займенник часто виконує функцію погляду зі сторони, фіксуючи просторове знаходження об'єктів. Для прикладу наводимо уривок твору Е. Хемінгуея “Острови в океані":

A man named Thomas Hudson, who was a good painter, lived there in that house and on the island the greater part of the year. After one has lived in those latitudes long enough....(Islands in the Stream, p. 3).

Українську версію було створено В. Митрофановим. Подаємо його переклад:

Власника будинку звали Том Хадсон, він був добрий художник і більшу частину року жив і прачював на цьому острові. Для людини, щэо довго прожила в цих широтах ... (Хемінгуей Е., T. 4, c. 201).

Бачимо, що В. Митрофанов не відходить від оригінального стилю і не допускає нехтування вказівними займенниками.

У роботах українських перекладачів можна простежити трансформацію дієслів та помітити тенденцію, яка характеризується відходом від нейтральних слів до стилістично забарвлених. Прикладами можуть слугувати переклади М. Пінчевського, який працював над такими романами, як “І сонце сходить” (“Фієста”), “По кому подзвін”, а також над п’єсою “П'ята колона". Він теж відмовився від словникових відповідників, які не могли задовольнити смаки вимогливого читача. У романі "I сходить сонце" М. Пінчевський перекладає хемінгуеївське would you like to go як ти хотів в би гайнути, чітко показуючи, що це радше мрія, а не задум. 
Ще одним прикладом перекладу В. Митрофанова ілюструємо відмову від нейтральної лексики на користь колоритної, що $є$ цілком правильним рішенням 3 огляду на те, що літературний герой Хемінгуея - це персонаж з народу, позбавлений будь-яких натяків на високе походження:

What are you looking at? Max looked at George. (The Fifth Column and the First Forty-nine Stories, p. 65).

Перекладач відхиляє словникову дефініцію дивитися на, замінюючи іï на стилістично забарвлене витріщатися.

У перекладах Л. Гончар та Ю. Покальчук також простежуються контекстуальні відповідники, які є наслідком застосування лексичної трансформації. Наприклад, в українській інтерпретації можна побачити опис руху потяга:

Коли поїд рушив, $і$ запилені дерева та дорога попливли назад...(Хемінгуей Е., Т. 4, с. 613).

Цікаво, що в оригінальному варіанті вжито стилістично нейтральне to move:

As the train started and the dusty trees and brown road commenced to move fast... (The Fifth Column and the First Forty-nine Stories, p. 115)

Іще більше таких трансформацій помітно в працях К. Сухенко та Н. Тарасенко. Приміром, описуючи фізичний стан персонажа роману Е. Хемінгуея "За річкою, в затінку дерев”, перекладачі трансформують англійське he walked у він доплентався:

Обличчя його посіріло, він насилу доплентався до конторки портьє. (Хемінгуей Е., Т. 3, c. 514).

В Е. Хемінгуея це речення звучало так: Trees, p. 152).

... and he walked, grey-faced, to the concierge's desk... (Across the River and into the

Використання фразеологізмів та тропів у перекладах творів Хемінгуея - це ще одна помітна риса українських перекладачів, яка виявляється у відтворенні діалогів чи при перекладах прямої мови. Когнітивна лінгвістика визнає, що метафори беруть свій початок у галузі конкретних понять для того, щоб пояснити абстрактні явища. Відповідно до цього судження лінгвісти засвідчують, що проза Хемінгуея заснована на відчутних реальних предметах і саме тому він створив функціональні, а не декоративні метафори. При інтерпретації діалогів чи монологів широко використовувалися фразеологізми та автентичні українські слова 3 урахуванням статі літературного героя, його віку, суспільного статусу і т.д. Проілюструємо це на прикладі перекладу В. Митрофановим речення з оповідання Е. Хемінгуея “Убивці”:

I don't even listen to it (Across the River and into the Trees, p. 74).

Вуха б мої вас не чули. (Хемінгуей Е., Т. 4, с. 408).

У цьому випадку використано фразеологізм, який $\epsilon$ широко розповсюдженим в українській мові. Перекладач навмисне уникає дослівного перекладу на кшталт $\boldsymbol{я ~ н а в і т ь ~ н е ~ х о ч у ~}$ це слухати, аби передати емоційний стан героя, який можна визначити лише 3 контексту.

Іще однією характерною рисою українських перекладів творів Е. Хемінгуея $\epsilon$ застосування прагматичної адаптації. Прикладами цього $\epsilon$ розшифрування незрозумілих українському читачеві абревіатур. К. Сухенко та Н. Тарасенко використовують цей прийом при інтерпретації твору “За річкою, в затінку дерев”:

The V.C. carries ten guineas, I believe. The D.S.C. is non-productive. (Across the River and into the Trees, p. 18).

За Хрест Вікторії, здається, платять десять гіней. Медаль «За відмінну службу» не дає ні иента. (Хемінгуей Е., Т. 3, с. 416).

Висновки та перспективи подальшого дослідження. Висока художня якість українських інтерпретацій - це результат творчого інтегрованого підходу перекладачів та їхніх високих професійних якостей. Крім того, беручи до уваги обмежені можливості для розвитку та невеликий тогочасний потенціал, можна стверджувати, що у 1979-1981 роках відбувся прорив, який ознаменував нову епоху в історії українських адаптацій творів Е. Хемінгуея. Відповідно до аналізу перекладів було виявлено ряд досягнень. По-перше, вітчизняне перекладознавство зуміло передати самобутність творів американського письменника засобами рідної мови, в тому числі власне українською лексикою, фразеологізмами тощо. По-друге, було приділено увагу 
творчому стилю Е. Хемінгуея, його лаконічності. Українські перекладачі навмисне уникали громіздких стилістичних конструкцій, тавтології та надмірного опоетизування 3 метою збереження творчого задуму письменника. Отже, переклади творів Е. Хемінгуея кінця 1970-х початку 1980-х - це великий крок у розвитку перекладацької діяльності, яка ознаменувала початок нової якісної епохи в історії українських інтерпретацій, що в свою чергу відкриває нові можливості для досліджень.

1. Denysova, Tamara. 2002. Istoriya amerykanskoyi literatury XX stolittya. Kyiv: Kyievo-Mohylianska akademiya.

2. Docenko, Rostyslav. 1971. Heminguej, yakoho mayemo i ne mayemo. Z nagody vydannya romanu "Po komu dzvin". Vitchyzna 6: 157-164.

3. Dyuryshyn, Dioniza. 1979. Teoriya sravnytelnogo izucheniya literatury. Moskwa: Progress.

4. Kovganyuk, Stepan. 1968. Praktyka perekladu (z dosvidu perekladacha). Kyiv: Dnipro.

5. Kramar, Volodymyr. 2016. "Zberezhennya indyvidualnoyi poetyky pysmennyka u perekladi (na materiali romanu "Ostrovy v okeani" E. Hemingueya)". Aktualni problemy filolohii ta perekladoznavstva. Khmelnytskyi 11: 80-85.

6. Kuharenko, Valeria. 1972. "Yazyk Ernesta Hemyngueya”. PhD diss., Moskwa.

7. Lanovyk, Mariana. 2006. Teoriya vidnosnosti hudozhnoho perekladu: literaturoznavchi proekciyi. Ternopil.

8. Orudzheva, Irina. 2014. "Problema adekvatnoi peredachi metafory Ernesta Hemyngueya v russkikh perevodah". Molodoi uchenyi 4: 1220-1224.

9. Romanenko, Natalia. 2018. "Vzayemodiya indyvidualnyh styliv avtora ta perekladacha u hudozhnyomu perekladi (na materiali tvoriv E. Hemingueya v ukrayinskii interpretaciyi V. Mytrofanova)". Pivdennyi arhiv. Filologichni nauky 74: 206-208.

10. Romanenko, Natalia. 2016. "Evolyuciya zasvoyennya spadshhyny E. Hemingueya cherez ukrayinski pereklady yak socialno determinovanyiproces". Naukovyi visnyk Mizhnarodnoho humanitarnoho universytetu. Ser: Filologiya 25(1): 129-132.

11. Tarnavskyi, Ostap. 1966. Tuga za mitom: Eseyi. New York.

12. Heminguej, Ernest. 1979-1981. Tvory : $v 4$ t. Kyiv : Dnipro. T. 3.

13. Heminguej, Ernest. 1979-1981. Tvory : v 4 t. Kyiv : Dnipro, T. 4.

14. Antoinette Fawcett, Karla L. Guadarrama García, Rebecca Hyde Parker. 2010. Translation: Practice in Dialogue. New York: CIPG

15. Hemingway, Ernest. 1966. Across the River and into the Trees. New York: Penguins book.

16. Hemingway, Ernest. 1970. Islands in the Stream. New York: Charles Scribner's Sons.

17. Hemingway, Ernest. 1972. The Fifth Column and the First Forty-nine Stories. London: J. Cape.

18. Sandra, Bermam. 2005. Nation, Language, and the Ethics of Translation. Princeton: Princeton University Press.

Василенко Ольга, Костюк Леся. Особенности становления украиноязычных переводов произведений Эрнеста Хемингуэя в XX веке. Статья посвящена исследованию исторических предпосылок появления украиноязычных переводов произведений Эрнеста Хемингуэя в ХХ веке и основных факторов, которые влияли на процесс становления украиноязычной практики. Отмечено, что отправной точкой этого сложного процесса стала публикация в конце 70-х - начале 80-х годов прошлого века четырехтомного издания произведений Хемингуэя в украинском переводе. Одним из актуальных объектов переводческого поиска служат художественные тексты модернистского и постмодернистского направления. Манера писателя характеризуется как лаконичная, сдержанная, экономная и суровая. Учитывая этот факт, переводчик должен тщательно подбирать языковые эквиваленты перевода, избегая буквализма и рассматривая произведение как целостную систему, передающую сюжетную линию. Важным шагом в становлении практики переводов произведений Э. Хемингуэя был уход от словарного буквализма к контекстуальному соответствию оригиналу. В работе определяются основные черты, присущие украиноязычным интерпретациям произведений американского писателя, в частности использование фразеологизмов и тропов при переводах прямой речи и диалогов, использование аутентичных украинских слов с учетом пола литературного героя, его возраста, социального статуса и т.д., а также применение прагматической адаптации. Анализируются способы передачи индивидуальной манеры Эрнеста Хемингуэя художественными средствами украинского языка с учетом национальных особенностей. Проведены параллели между социокультурной жизнью Украины в условиях ХХ века и развитием переводческой деятельности на примере произведений Хемингуэя. Отмечено, что общественнополитическая ситуация в стране определяла путь развития переводческой практики: это - препятствие антиукраинской политики появлению украиноязычных переводов как таковых и негативное отношение к сущности произведений Хемингуэя. Определены главные факторы, задававшие вектор переводческой деятельности и прямо или косвенно формировавшие основные ее тенденции. В контексте социальных факторов проанализированы направления влияния и определена их роль в формировании переводческой деятельности в Украине во второй половине прошлого века. Указаны основные достижения украинских переводчиков в процессе интерпретации произведений Эрнеста Хемингуэя на украинском языке.

Ключевые слова: индивидуально-авторский стиль, перевод, методы перевода, лексическая трансформация, контекстуальный эквивалент. 
Vasylenko Olha, Kostyuk Lesya. The Peculiarities of the Formation of Ukrainian-Language Translations of Ernest Hemingway's Works in the $\mathbf{X X}^{\text {th }}$ Century. The article deals with the study of the historical backgrounds for the emergence of Ukrainian-language translations of Ernest Hemingway's works in the twentieth century, and the main factors that determined the Ukrainian-language practice. It is noted that the starting point of this difficult process was the publication in the late 70s - early 80s of the last century of a four-volume edition of Hemingway's works in Ukrainian translation. One of the urgent objects of the translation search is the works of fiction of modern and postmodern directions.

The manner of the writer is characterized as concise, restrained, economical and strict. Considering this fact, the translator must select the language equivalents of the translation carefully, avoiding literalism, and considering the analysed work as a whole system that conveys the storyline. An important step in establishing the practice of translating the works of E. Hemingway was the recession from vocabulary literalism to contextual equivalent to the original.

The article determines the main characteristics of Hemingway's works' Ukrainian modern interpretations, such as the usage of phraseological units while translating direct speech and dialogues, the usage of authentic Ukrainian words considering the character's sex, age and social status. The usage of pragmatic adaptation is also frequent.

The ways of expressing the individual manner of Ernest Hemingway with the methods of fiction of the Ukrainian language are analyzed considering national features. The parallels between the social and cultural life of Ukraine are conducted in the conditions of the twentieth century and the growth of the translating activity on the basis of that of Hemingway's works.

It is indicated that the social-political situation in Ukraine restrained the development of translating practice: antiUkrainian policy blocked the publishing of Ukrainian translations. The negative attitude towards the plots of Hemingway's works was another negative factor.

The main factors which set the vector of translating activity and formed its main tendencies are identified. In the context of social parameters, the ways of their influence and their role in the forming of Ukrainian translating practice are analysed. The main achievements of Ukrainian interpreters in the process of interpretation of Ernest Hemingway's works are singled out.

Key words: individual author's style, translation, translation methods, lexical transformation, contextual equivalent.

DOI: https://doi.org/10.32782/2410-0927-2020-12-6

УДК 371:811.111

Світлана Волох

\section{ВИКОРИСТАННЯ ІГРОВИХ ТЕХНОЛОГІЙ НА ПРАКТИЧНИХ ЗАНЯТТЯХ 3 АНГЛІЙСЬКОЇ МОВИ В ЗАКЛАДАХ ВИЩОЇ ОСВІТИ}

У статті висвітлено питання застосування ігрових технологій у навчанні англійської мови в закладах вищої освіти, зіставлено традиційні підходи до навчання та ігрові технології. Досліджено сутність поняття гейміфікації в освітньому процесі, визначено іï переваги та недоліки порівняно з традиційними методами навчання, наведено приклади застосування гейміфікації в освіті. Завданням статті $є$ обгрунтувати сприяння розвитку нових, прогресивних підходів до навчання та розширення використання їх під час практичних занять 3 англійської мови у вищій школі. У дослідженні застосовано описовий і зіставний методи, а також процедуру класифікації для аналізу явища гейміфікації та визначення її основних рис.

На сучасному етапі традиційні форми та методи навчання дійсно стають менш ефективними серед молоді через те, що молоді люди мають низьку мотивацію до навчання та їхнє повсякденне життя перенасичене використанням електронних гаджетів. Тому одним із засобів покращення навчання є використання ігрових технологій, або “гейміфікація”, Digital Game Based Learning (DGBL) - навчання, під час якого використовуються комп’ютерні ігри.

Основними перевагами гейміфікації $\epsilon$ мотивація студентів, залучення їх до активної діяльності, запровадження елементу змагання, заохочення, докладання більших зусиль до навчання та концентрації уваги, поліпшення атмосфери на занятті. Використання гейміфікації можливе без інформаційних технологій, але використання комп’ютерних ігор або онлайн - компонента збагатить навчальні ігри та піде на користь підготовці фахівців. Труднощами запровадження гейміфікації в навчальний процес визначено трудомісткість підготовки навчальних завдань, необхідність використання технічних засобів, можливі складнощі у використанні ТЗН на заняттях і комп'ютерна грамотність викладачів.

В Україні гейміфікація не є поширеною, проте 3 огляду на ряд переваг у порівнянні традиційними підходами може бути поступово впровадженою в освітній процес з метою осучаснення викладання іноземних мов у ЗВО України. Прикладами використання ігрових технологій у навчанні $є$ інтернет-сервіси і освітні платформи. Duolingo - це сервіс для самостійного вивчення іноземної мови, який разом із тим надає послугу щодо його використання в навчальних закладах. Edmodo та Kahoot є навчальними платформами на основі ігор, які можливо використовувати на заняттях іноземної мови.

(C) Волох С., 2020 